\title{
American Pragmatism and European Social Theory
}

Holmes, Durkheim, Scheler, and the Sociology of Legal Knowledge

Frederic R. Kellogg

\section{CpenEdition}

Electronic version

URL: http://journals.openedition.org/ejpap/773

DOI: 10.4000/ejpap.773

ISSN: 2036-4091

Publisher

Associazione Pragma

Electronic reference

Frederic R. Kellogg, « American Pragmatism and European Social Theory », European Journal of

Pragmatism and American Philosophy [Online], IV - 1 | 2012, Online since 23 July 2012, connection on

20 April 2019. URL : http://journals.openedition.org/ejpap/773 ; DOI : 10.4000/ejpap.773

This text was automatically generated on 20 April 2019.

\section{c) (i)}

Author retains copyright and grants the European Journal of Pragmatism and American Philosophy right of first publication with the work simultaneously licensed under a Creative Commons AttributionNonCommercial-NoDerivatives 4.0 International License. 


\title{
American Pragmatism and European Social Theory
}

Holmes, Durkheim, Scheler, and the Sociology of Legal Knowledge

\author{
Frederic R. Kellogg
}

1 Kenneth Stikkers has illuminated the convergence between Max Scheler's phenomenological sociology and a central theme of nineteenth century American pragmatism: their joint break from both Platonic and Aristotelian philosophy through the insight that knowledge neither precedes our experience of things (ideae ante res), as in Platonic idealism, nor follows from experience in an empirical correspondence with an objective world, the Aristotelean model (ideae post res). Scheler followed American pragmatism's insight that knowledge resides in concrete human acts (ideae cum rebus), where it becomes functionalized. Chicago pragmatists, in turn, recognized the importance of Scheler's pioneering statement of the "sociology of knowledge," and its commonality with pragmatism's emphasis on community inquiry. (Stikkers 2009: 80-2)

How, given this insight, is knowledge to be understood? Two features stand out in the functional model that are hidden by the classical Platonic and Aristotelean approaches: the dynamic and changing nature of knowledge and its products, and their intimate connection with human conduct and experience. Both of these are obscured by synchronic tendencies of analytical theory, and have been brought to light within specific realms of inquiry, as in contemporary science studies, where a burgeoning but controversial "sociology of scientific knowledge" has emerged in the wake of Kuhn's Structure of Scientific Revolutions (see Barnes et al. 1996).

3 Stikkers recounts the influence of the pragmatist William James on the German scholars Wilhelm Jerusalem and Max Scheler, and notes that Charles Peirce had already suggested, prior to Dilthey and Durkheim and without any apparent benefit from the insights of Marx, that the forms of human knowing are fundamentally forms of social life, without reducing the latter to the forms of economic life. This radically naturalist insight became central to early writings in the sociology of knowledge, and has influenced post-Kuhnian science studies. 

convergence of American pragmatism and this strain of European social theory, it should not be surprising to find something comparable to a sociology of legal knowledge in the work of pragmatism's classical legal theorist, Oliver Wendell Holmes Jr. Pragmatism grew out of the Metaphysical Club, and it is well known that half of the original members of the Metaphysical Club were lawyers.

Bruce Kuklick and others have recounted the common influences on all the members of the Club such that we might expect parallels in the conception of law (Kuklick 1977; Kellogg 2007). I will focus here on the early writings of O. W. Holmes Jr. Holmes is conventionally interpreted principally as a forerunner of empirical legal realism. I suggest that his pre-judicial writings sketched the outline of a socialized epistemology of law, and an evolutionary formation and maintenance of legal rules and concepts.

\section{The Unlikely Comparison of Holmes and Durkheim}

In 1899, two years before the publication of Emile Durkheim and Marcel Mauss's Primitive Classification, Oliver Wendell Holmes Jr. made the following comment in an address later published as "Law in Science and Science in Law":

It is perfectly proper to regard and study the law simply as a great anthropological document. It is proper to resort to it to discover what ideals of society have been strong enough to reach that final form of expression, or what have been the changes in dominant ideals from century to century. It is proper to study it as an exercise in the morphology and transformation of human ideas. (1899: 212)

This extraordinary passage, emphasizing "morphology" over the dominance of fixed analytical and conceptual theories of law, reflects research twenty-five years earlier, in the period 1873-6, when Holmes turned from an earlier influential version of analytical jurisprudence (the Lectures in Jurisprudence of John Austin) to writings on legal history, anthropology and primitive culture, to consolidate a theory of legal transformation.

In an 1876 essay, "Primitive Notions in Modern Law" (1876), Holmes observed that many of the rights and duties recognized in Anglo-American law were "survivals" of "the primitive notion, that liability attached directly to the thing doing the damage." Moreover, "the various considerations of policy which are not infrequently supposed to have established these doctrines, have, in fact, been invented at a later period to account for what was already there--a process familiar to all students of history" (1876: 423). He would go on to apply this insight to an account of case-by-case "growth" of legal liability, eventually extending it to all areas of law. Thereafter he drew on this transformational scheme for insights into developing legal doctrine throughout his influential judicial career (Kellogg 2007: 118-56).

9 In comparison, Durkheim and Mauss asked, in Primitive Classification, the more general question, "[W]hat leads men to classify?" For them it seemed that the answer lay in the most rudimentary forms of organization in the development of society. They concluded that "[T] he first logical categories were social categories; the first classes of things were classes of men, into which these things were integrated. It was because men were grouped, and thought of themselves in the form of groups, that in their ideas they grouped other things, and in the beginning the two modes of grouping were merged to the point of being indistinct" (1963: 82-3). "Thus the history of scientific classification is, in the last analysis, the history of the stages by which this element of social affectivity has 
progressively weakened, leaving more and more room for the reflective thought of individuals. But it is not the case that these remote influences which we have just studied have ceased to be felt today. They have left behind them an effect which survives and which is always present; in it is the very cadre of all classification, it is the ensemble of mental habits by virtue of which we conceive things and facts in the form of coordinated or hierarchized groups" (88).

While for the past century the intellectual legacies of Holmes and Durkheim have occupied separate academic worlds, both drew a similar demarcation between what they saw as a primitive "affective" stage of civilization and a modern "rational" stage, while insisting on the continuing influence of the former upon the latter, itself incrementally transformed by increasingly "reflective" intelligence. Thus there are common elements in both: transformational change with surviving vestigial elements, suffusing logical method and undermining logical essentialism, the bedrock of analytical thinking. For both, a community- or society-focused historical process is at the root of the existence and management of ordered conceptions. For both also, the ongoing role of classification in human intelligence is a fundamental concern. The main difference is that Durkheim and Mauss set out to discover the origins of human classification in general, finding them in social structure and the evolving nature of solidarity, while Holmes's interest was drawn to its operation in Anglo-American law.

11 In that sense Holmes began his study of legal classification in medias res, focusing on his own 19th century context. Having in 1869 taken over the editorship and revision of the principal American legal encyclopedia, Kent's Commentaries on American Law, he equipped himself to compare the varieties of developing legal doctrine with the recent and influential analytical system of John Austin's Lectures in Jurisprudence, published in London in 1861. The Lectures first came to his attention as he left Harvard College to join the Union Army at the onset of the American Civil War. His focus on Austin continued after returning to Cambridge in 1864, where he attended Harvard Law School, engaged in philosophical discussions with his peers, became the editor of Kent's Commentaries, and wrote critical and formative essays for the American Law Review.

By 1876-7 he had been drawn into the examination of legal history and early culture and institutions, "to prove the historical truth of a general result, arrived at analytically [...] five years ago" (1877: 641). That result involved a reconsideration of the Austinian project of universal classification and it is intimately connected with his famous opening line in The Common Law: "the life of the law has not been logic, it has been experience." This turning point is fundamental to understanding his thought and career.

13 From introductory courses on jurisprudence, American law students are still familiar with Austin's famous command definition of law. Less familiar is the detailed character of Austin's Lectures, embodying an attempt to establish a universal arrangement of law, which he outlined as a system of rights (Austin 1861). Holmes first explored this thesis by advancing an alternative system based on the concept of duty (1870). An intensive comparison of categories with cases, extending over several years, eventually led to rejection both of Austin's command definition and his logical arrangement of law as a system of rights, and indeed of any universal analytical scheme.

14 This highlighted the question - prompted by his observations of the continuing influence of historical anomalies - of how the ordered hierarchies of legal classification and their manifestation in a structured system are arrived at. Looking at the process of change within the existing system, and in the context of a course taught to Harvard 
undergraduates, Holmes characterized his own definition of law as "prediction" of judicial decisions (1872: 92).

After his general study of classification with Mauss, Durkheim would later move more specifically to law. In The Division of Labor in Society (1933) he hypothesized an evolution of diminishing reliance on criminal in favor of civil forms of legal liability and procedure, and interpreted this as supporting the thesis of transformation from "mechanical" to "organic" social solidarity. Durkheim now distinguished criminal and civil liability as reflecting distinct forms of social solidarity. Holmes, immersed in the case-law of his revision of Kent's Commentaries, would instead bring the two forms together in a uniform theory of criminal and civil liability.

Holmes would characterize historical change (he avoided the term "evolution") as having universally transformed standards of legal liability from "moral" to "external," intending by these terms to highlight the gradual de-emphasis of an element of subjective blame rooted in primitive revenge. Equally important, he saw the actual process of transformation - and here lies his insight into the cumulative mechanism of legal classification - rooted in the response of legal institutions to ongoing social conflict. It would inform both his thought and later judicial practice.

The legal sociologist Roger Cotterrell has illuminated the continuing influence of Durkheim on socio-legal studies and social theory in general (2010a). We might compare this to the relative lack of influence, or even interest, in Holmes's transformational theory. Over the years since his death Holmes has rarely been mentioned among accounts of socio-legal theory or legal sociology. He is missing from Peter Stein's overview of Theories of Legal Evolution: the Story of an Idea (1980), as well as from Alan Watson's The Evolution of Law (1985) and Norbert Rouland's, Legal Anthropology (1994). While his theory of liability qualifies as a contribution to legal anthropology, it is not widely recognized as such.

18 This has obscured the contemporary relevance of Holmes's 1899 comment on the law as "a great anthropological document," worthy of study "as an exercise in the morphology and transformation of human ideas." The remark suggests that, with Durkheim (Cotterrell 2010b: 4), he saw the development of law as illuminating basic moral concerns. His recognition of a deep influence of conflict, and the survivals of a primitive past, puts a somewhat darker cast on the prospects of society than the visions of his contemporaries Peirce and James. While he is considerably less optimistic than Durkheim about reform, he came to recognize a place for meliorative intelligence in the common law that would gain the interest of John Dewey.

19 Nevertheless, Holmes is conventionally interpreted as a legal positivist and as a forerunner of legal realism. Early twentieth century legal realism was influenced by then contemporary social and behavioral science. It emphasized legal reform, motivated by a reaction against the false certainty of "formalist" and "mechanical" jurisprudence (see White 1984, 1986). As noted, Holmes (1872a: 92) had defined law as prediction of what courts will decide and enforce, which was too readily identified with judicial behaviorism or instrumentalism. In essence, it was entirely different.

Critical evidence is found in two formative papers that Holmes wrote in the 1870s. In the first (1870), he notes that Anglo-American common law "decides the case first and determines the principle afterwards," in a process of gradual cumulative classification and generalization that he called "successive approximation." He cautions here against 
judges giving premature reasons in deciding unfamiliar cases, and advocates highly particularized decisions in the early stage of inquiry into new classes of dispute. The judge should simply apply a standard of prudence or the foreseeability of harm under novel conditions.

Citing a comment by Lord Chief Justice Mansfield, Holmes drew on John Stuart Mill's criticism of the syllogism, which Mill (citing the same comment) saw as reasoning not from general to particular but from "particulars to particulars." In his famous System of Logic (1843), which Holmes read in 1867, Mill declared that the general is simply used as a guide. But for Holmes in 1870, the relevant general cannot be used as a guide for new particulars, because it does not yet exist. How does it come to be? As new problems arise and new disputes are decided, gradually a pattern emerges.

It is only after a series of determinations on the same subject-matter, that it becomes necessary to 'reconcile the cases,' as it is called, that is, by a true induction to state the principle which has until then been obscurely felt. And this statement is often modified more than once by new decisions before the abstracted general rule takes its final shape. A well settled legal doctrine embodies the work of many minds, and has been tested in form as well as substance by trained critics whose practical interest it is to resist it at every step. (1870:1)

This conception is open to the recognition that legal generalization is influenced by feedback from and adjustment within society. In later essays Holmes makes it plain that he drew on the reliance of 19th century courts upon jury decisions for deriving, in successive judgments, the applicable standards of care in a given jurisdiction for a particular form of tort liability. (Holmes 1873; Kellogg 2007: 98, 161). These early observations - made in the period during which he was still considering Austin's universal analytical taxonomies - already lead away from the path that analytical legal theory followed toward conceptual jurisprudence in the twentieth century, and instead toward a focus like that of Julius Stone on the influence of social factors and the relevance of precedent to a system of incremental legal classification (Stone 1985). Despite the association of Holmes with legal realism, they also lead less toward judicial behaviorism and more toward a sociology of legal knowledge, acknowledging the social context that connects the formation of legal rules and principles directly with resolution of clashing patterns of conduct. This emphasis on conflict over solidarity further distinguishes Holmes from Durkheim's approach to the source and morphology of concepts within the legal system, if not within society itself.

The early Holmes essays suggest a distinctive vision of the 19th century common law process, whereby normative inquiry, and normative knowledge, begins with disturbances in the social fabric channeled into systematized and participatory dispute resolution. It was participatory in that Holmes gave the jury a critical role in this picture and recognized the influence of discrete geographical communities on the formation of variations in the general standards of liability (Holmes 1872: 119). Thus, the repeated "series of determinations" was in actual practice an accumulation of judgments in matters to which the courts were open as a matter of jurisdiction, coming in under categories of liability defined by the pleadings, which assigned legal claims a preliminary form of classification. Thereafter they gained further juridical characteristics by reason of successive judgments for or against the injured parties, which were cumulatively organized as judges and scholars "reconciled the cases."

To illustrate, we may take an example of liability for damage resulting from a collision of ships under sail. With the vagaries of wind and tide, repeated collisions brought ship 
owners into the courts claiming money for loss of cargo and damage. We might envisage a detailed account unfolding in the courtroom of how two ships collided, perhaps at night. When did one crew see the other ship, what did the crew do then? Sailing is tricky and complicated, and in the absence of a clear error, we may assume a fair hearing so that the judgment goes against the vessel that, perhaps on a slight preponderance of the evidence, appeared least prudent under the circumstances. Can we fairly say the early case was decided by a rule of law?

Over time, similar collisions occur and prudent practices develop to the point where the courts can and will say, yes, this ship or that was burdened and failed to display a certain light or post a lookout or douse a certain sail to avoid the collision. An illustration of this might be the display of colored lights on ships at night, identifying sailing ships, anchored ships, tugboats, barges. Their first introduction presumably led to cautionary practices and thence to legal standards and rules. Thus does the class of "collision cases" develop into general standards and rules, over time. We should note the participation of multiple communities of actors, sailors and ship owners as well as lawyers, judges, juries, scholars, and legislators.

Under this scenario, legal normativity emerges as a web or network of standards stemming from disparate practices and woven together by professionals whose mission it is to impose coherence, predictability, and consistency. This is not, I hasten to say, a precise historical account, but rather a rough simulation drawn from the early essays by Holmes, which in turn is the product of several influences: a close study of 19th century English and American cases, broad reading in philosophy as well as law, an attitude toward knowledge shared with his friends in and around the Metaphysical Club, and the influences on them from the Scottish Enlightenment, applied to their readings of Kant, Hegel, and Darwin. This mix of influences has been said to have led pragmatism toward a radically naturalized reading of Kant and Hegel (Margolis 2010).

You may see elements of a Darwinized Hegel in Holmes's approach to rule-making, influenced perhaps by another member of the Club (and his only admitted mentor) Chauncey Wright, who in 1873 published an influential essay "The Evolution of SelfConsciousness," written at the encouragement of no less than Charles Darwin himself. Holmes appears to have absorbed Wright's attitude, and he took it in a different direction, toward the development of legal intelligence, as part of a socialized ordering process. And now we can sense what he implied in defining law as prediction of what courts will do. Law is not an already-set system of rules with a preexisting answer for every new case. It is a constantly developing system of classification, influenced by multiple communities of inquiry.

Three years later Holmes wrote another important essay (1873). Here he addressed the issue of cases that arise in the context of conflicting authorities. Legal cases reaching the appellate stage emerge within an elaborate context of preexisting law. The more difficult cases appear uncertainly placed between two (or more) opposing precedents or general principles. An example in the 1873 essay is the conflict of nuisance with property rights, as in disputes between neighboring landowners over the placement and height of a wall. Upon repeated instances, in the absence of local legislation, the courts eventually work out a formula for placement and height. Thus are opposing generals reconciled over time, again through fallibilist inquiry. Holmes had by now moved a considerable distance from Austin's analytical approach. 
Analytical theory in jurisprudence has viewed law as an authoritative and comprehensive body of doctrine. The assumption that it is comprehensive is disturbed by the persistent difficulty of close or "hard" cases. Thus the analytical attitude gives rise to skepticism; the difficulty is seen as a deficiency residing in the body of doctrine itself, or in the law's "nature." Many legal realists went to the opposite extreme in seeing uncertain cases as "legally indeterminate." The idea of indeterminacy invites the explanation of judicial behaviorism or instrumentalism - law is the sum of subjective influences on judges, or their immediate sense of the "best" consequences. It also opens the conversation to the presumptive legitimate judicial appeal to "moral" or "fundamental" principles.

In the problem of the doubtful or difficult case we find the distinctiveness of Holmes's theory of law. Holmes sees the doubtful case as a stage of inquiry and classification. In his 1873 essay, Holmes elucidated an alternative to the analytical model. In the doubtful case, opposing generals are not reconciled either by analytical logic or judicial behaviorism or instrumentalism, but again by a social process of experimental, successive approximation. He applied the earlier cumulative model of 1870 to the problem of resolution of conflicts among rules and precedents. Again, his approach was, "particularize first, generalize later." Here is the key passage:

The growth of the law is very apt to take place in this way: Two widely different cases suggest a general distinction, which is a clear one when stated broadly. But as new cases cluster around the opposite poles, and begin to approach each other, the distinction becomes more difficult to trace; the determinations are made one way or the other on a very slight preponderance of feeling, rather than on articulate reason; and at last a mathematical line is arrived at by the contact of contrary decisions, which is so far arbitrary that it might equally well have been drawn a little further to the one side or the other. (1873: 654)

Holmes suggests here a process whereby new experience falls into a grey area between existing generals, eventually revealing a new pattern which he describes as a "line," ultimately refining or redefining the generals themselves.

Given the historical background that drew his attention in 1876, the context within which new cases arrive is yet more complex. Holmes's account of the survivals of primitive vengeance was drawn from contemporary law. In his "Primitive Notions in Modern Law" (1876), Anglo-American maritime or admiralty law offered an example of the phenomenon of "survivals," in particular of "the primitive notion, that liability attached directly to the thing doing the damage". The aggrieved ship owner whose own ship suffered damage in a collision could not recover more than the value of the defendant's own vessel. Holmes saw this as influencing later rationales for the limitation of liability, observing that "the various considerations of policy which are not infrequently supposed to have established these doctrines, have, in fact, been invented at a later period to account for what was already there - a process familiar to all students of history" (1876: 423).

\section{Contemporary Law}

Do rules of law still emerge from meandering patterns of individual judgments, as Holmes suggested 140 years ago, or is everything handled by legislation and administrative rulemaking? How about a new problem like assisted suicide? This class of dispute started out as a series of criminal prosecutions of doctors for murder, until the opposing claim of patient autonomy got some traction, from constitutional language, applied to changing 
medical circumstances. The problem soon found its way to the appellate courts. In 1999 Professor Cass Sunstein wrote a book called A Case at a Time: Judicial Minimalism on the Supreme Court, in which he cautioned the same thing as Holmes did in 1870: decide the cases one at a time, it's often premature to lay down a sweeping general rule. Ultimately, we may need legislation, but even that can't come too soon, before the exploratory stage, which includes a process of feedback and adjustment from non-lawyers. Legislation is itself a stage in the process of inquiry.

An implication of this is to qualify the classical model of democratic social choice, famously criticized by Kenneth Arrow. Social choice through law is ongoing outside the electoral cycle, for good or ill, in the process of conflict resolution, influenced by feedback from relevant communities. As with assisted suicide, each successive decision may respond to feedback from diverse communities of interest, including medical, legal, and academic professionals, senior citizens, lobbying groups, and so on. Decisions are also influenced by social adjustment and the adoption of new practices, from medical procedures to living wills.

What are the key elements here? 1) We are looking at legal cases not singly, as raising an isolated question of existing law against a synchronic analytical background, but as stages of inquiry into social problems, and against a diachronic background. 2) Notwithstanding the role of "great judges," the guiding intelligence is not individual but social - hence it implies a socialized epistemology of legal rules and concepts. 3) Inquiry itself is generated not solely by pure dispassionate analysis, but also by the urgency of conflict and the need for resolution; the legal "conversation" is messier than any ideal model of dialogue. 4) Inquiry takes place in a context of preexisting generals to which legal institutions look back even while plotting new cases in relation to them. 5) The judicial role of comparing and contrasting can be viewed as an incremental and cumulative line-drawing, influenced by many factors over time. 6) Judges are members of a community of inquiry, but acting within a network of other communities, both expert and lay. 7) The interaction between disparate communities operates during the line-drawing process as a "feedback loop" from judicial decisions to their effects, which feeds new experience into the judicial system.

\section{Contemporary Science Studies}

These elements outline a view of law, albeit one drawn from Anglo-American experience, as both a process of social inquiry and a specialized system of classification. A comparable view of the development of natural science has become increasingly evident since the appearance in 1962 of Thomas Kuhn's Structure of Scientific Revolutions - although Ludwik Fleck's Genesis and Development of a Scientific Fact had already offered such a view in 1935. In their book Scientific Knowledge: A Sociological Analysis (1996), leading representatives of the "Edinburgh School" of science studies outline an approach to contemporary science as another specialized, moving system of classification (46-80). Scientific research responds to social problems; its major figures draw more heavily on research traditions than on brilliant insights; it often involves conflicts among separate research traditions, and seemingly incommensurable principles, like the notions of particle versus flux in electricity; experiments can be seen as exercises in classification; and scientific theorists are members of a professional community of inquiry, acting within a network of other communities, both expert and lay (see e.g. Kellogg 2010). 


\section{Scheler and the Sociology of Knowledge} which remain today. Critics have interpreted both Scheler and Mannheim as advancing a radical form of deflationary anti-foundationalism, reducing all thought to its social origins, regardless of a constraining world. Mannheim had cautiously defined the field as follows: "The principle thesis of the sociology of knowledge is that there are modes of thought which cannot be adequately understood as long as their social origins are obscured" (1936: 2). In fairness to him, the relevance of social origins made but a modest demand on the already developing naturalism of western philosophy, already begun with Hume, Kant, and Hegel (Stikkers 2009: 67). But the main currents in western philosophy turned elsewhere.

41 In the years following World War I, western philosophy sought a renewal of secure foundations in a turn toward rigorous reductive analysis. Analytical philosophy came to dominate American universities even as strains of "postmodernism" seeped in from Continental sources. The late resurgence of pragmatism in this context transformed the environment. Drawing on W.V.O. Quine and Donald Davidson, Richard Rorty made pragmatism fashionable among analytical philosophers, welcoming rigorous analysis into themes explored by James and Dewey, reconciling them with postmodern anti- 
foundationalism. The early emphasis on fallibilism, with its tentative, social, and experimental aspects, has been downplayed.

Pragmatism's post-Rorty renewal has scattered it in several directions, such that discussion of a historic mission or essential insight may be impossible, nothwithstanding the heroic efforts of pragmatists like Joseph Margolis to establish a contemporary position and chart a future course (2010). The widest gulf would seem to be that between the analytical neopragmatism now carried forward by Robert Brandom and others influenced by Rorty, and the historicist, fallibilist tradition emergent from Peirce, James, and Dewey, the non-analytical strain that influenced Scheler. This essay brings Holmes under the latter umbrella, suggesting a connection with recent empirical and historical studies in the sociology of scientific knowledge.

With this purpose in mind, Kenneth Stikkers's (2009) recent account of the early association of Scheler with American pragmatism, in the published proceedings of a conference on pragmatism and constructivism, is a welcome contribution. Stikkers had previously published an introduction to Frings's translation in 1980 of Scheler's "Probleme einer Soziologie des Wissens" (1980). There, Scheler outlines its relation to a range of topics, including science, religion, politics, international relations, and other speculative themes of his phenomenological sociology. Writings of the early pragmatists provided Scheler with an important resource for his systematic understanding of the post-war period of crisis and its global relevance. He credited pragmatism with disclosing the fundamental practical basis of knowledge and offering the first genuinely novel alternative to rationalist and empiricist epistemologies. Citing James, knowledge for Scheler was a function of the dynamic human creative interaction with the world; ideas do not merely report or mirror reality, but emerge within practical human engagement, and in doing so transform the world (James 1975: 104-6).

In his opening to "Problems of a Sociology of Knowledge," Scheler summarized the overall context:

The following studies have a limited goal. They are an attempt to point out the unity of a sociology of knowledge as a part of the sociology of culture, and above all to develop systematically the problems of such a science. [...] They attempt to bring about some systematic unity in the rhapsodic and disordered mass of problems at hand, some of which have already been taken up in detail by science and others only half met or barely suspected, problems posed by the fundamental fact of the social nature of knowledge and of its preservation and transmission, its methodical expansion and progress. (Scheler 1980: 33)

45 He went on to include within this "the relationship of the sociology of knowledge to the theory of the origin and validity of knowledge (epistemology and logic), to the genetic and psychological studies of knowledge as it evolves from brutes to man, from child to adult, from primitive to civilized man, from stage to stage within mature cultures," to "the positive history of various kinds of knowledge."

Holmes, drawing on a common perspective with the early pragmatists, had already cast light on the social nature of legal inquiry, the origin of liability in revenge, and its genesis and transformation in evolving from "brutes to man." Scheler's postwar interest in the role of conflict in the emergence of values is shared in Holmes's 1899 comment, calling law a resource "to discover what ideals of society have been strong enough to reach that final form of expression, or what have been the changes in dominant ideals from century to century." While Scheler is a more speculative thinker, Holmes, as a veteran of an earlier bloody conflict, came to share similar concerns from a particularist and historical 
focus. Having rejected a strictly analytical approach to law before writing his major work, which led directly to his judicial career, he would anticipate Scheler's focus on transformation in his 1899 comment that law provided "an exercise in the morphology and transformation of human ideas."

\section{Conclusion}

47 In comparing such disparate sources, a purpose of this paper has been to advance an approach toward a sociology of legal knowledge that brings the subject into a coherent relation with a general sociology of knowledge, as well as with recent studies in the sociology of scientific knowledge.

In this paper I have compared Holmes's evolutionary theory, set forth in The Common Law, with Durkheim and Scheler. Unlike Durkheim, Holmes does not hold that categories of thought reflect features of group organization and social solidarity. The nature and modes of legal classification primarily emerge against a historical background from resolution of conflicts among habitualized conduct of groups and interests, eventually giving rise to rules and principles, embodied not in pure language but also, necessarily, in general patterns of conduct. It is more particularist than Scheler, rooted in conflict resolution as informing a discrete form of dialogue. While deeply skeptical of progress, Holmes's model allows a role for emergent meliorative intelligence in revising vestigial habits and overcoming established paradigms.

Transformation is a key theme to which I have alluded throughout this essay. Transformation is the element in human experience to which both Holmes and Durkheim looked in their studies of law. It is the attribute of human experience which, to sheer analysis of concepts and language, however rigorous, remains obscured. It is an aspect of philosophy and social theory that continues to influence the traditions of pragmatism and the sociology of knowledge, even while both have made it an essential focus of their own self-understanding; that is, the two traditions have seen their own guiding perspectives reflexively, as themselves subject to transformative experience.

\section{BIBLIOGRAPHY}

AUSTIN John, (1861), Lectures in Jurisprudence, London, John Murray.

BARNES Barry, BLOOR David \& John HENRY, (1996), Scientific Knowledge: A Sociological Analysis, Chicago, Chicago University Press.

CotTerrell Roger, (2010a), Émile Durkheim: Justice, Morality and Politics, Farnham, Ashgate.

COTTERRELl Roger, (2010b), “Golden Ages: Notes on the Future of Sociology of Law, With Some

Comments on its Past, on Poland, and on Jazz," Social Science Research Network, [papers.ssrn.com/

sol3/papers.cfm?abstract_id=1715564].

DURKHEIM Émile, (1933), The Division of Labor in Society, New York \& London, The Free Press. 
DURKHEIM Émile \& Marcel MAUSS, (1963), Primitive Classification, Chicago, University of Chicago Press.

EDMOND Gary \& David MERCER, (1998), "Representing the Sociology of Scientific Knowledge and Law," Science Communication, 19 (4), 307-27.

FREEMAN Michael, (2006), Law and Sociology: Current Legal Issues 8, Oxford, Oxford University Press. HERGET James E., (1990), American Jurisprudence 1870-1970, Houston, Rice University Press.

HOLMES Oliver Wendell Jr., (1870), “Codes, and the Arrangement of the Law," American Law Review 5 (1), 13, at 1. Reprinted in Kellogg 1984, 77.

HoLmes Oliver Wendell Jr., (1872), “Book Notice," American Law Review 6: 723-5, at 724. Reprinted in Kellogg 1984, 91.

HoLmes Oliver Wendell Jr., (1873), “The Theory of Torts,” American Law Review 7: 652-63, at 654.

Reprinted in Kellogg 1984, 117.

Holmes Oliver Wendell Jr., (1876), “Primitive Notions in Modern Law," American Law Review 10:

422-39, at 1. Reprinted in Kellogg 1984, 77.

Holmes Oliver Wendell Jr., (1877), “Primitive Notions in Modern Law. No. II," American Law Review 11: 641-60, at 641. Reprinted in Kellogg 1984, 147.

HOLMES Oliver Wendell Jr., (1896), “The Path of the Law," in Collected Legal Papers, New York, Harcourt, Brace, 179.

HOLMES Oliver Wendell Jr., (1899), “Law in Science - Science in Law," in Collected Legal Papers, New York, Harcourt, Brace, 210.

HOVENKAMP Herbert J., (1985), “Evolutionary Models in Jurisprudence,” Texas Law Review, 64 (4), 645.

JAMES William, (1975), Pragmatism. In The Works of William James, ed. Frederick H. Burkhardt et al., Cambridge, MA, Harvard University Press.

KELLOGG Frederic R., (1984), The Formative Essays of Justice Holmes: The Making of an American Legal Philosophy, Westport, CT \& London, Greenwood Press.

KELLOGG Frederic R., (2007), Oliver Wendell Holmes Jr., Legal Theory, and Judicial Restraint, Cambridge, Cambridge University Press.

KELLOGG Frederic R., (2009), “The Construction of Legal Positivism and the Myth of Legal Indeterminacy," [papers.ssrn.com/sol3/papers.cfm?abstract_id=1536124].

KELLOGG Frederic R., (2010), “Law and Science as Forms of Inquiry: Toward a Comparison of Legal and Scientific Knowledge," [papers.ssrn.com/sol3/papers.cfm?abstract_id=1509651].

KENNEDY Duncan, (1994), “A Semiotics of Legal Argument," in Academy of European Law, ed., Collected Courses of the Academy of European Law, vol. III, Book 2, 309, Netherlands, Kluwer Academic Publishers.

KUHN Thomas, (1962), The Structure of Scientific Revolutions, Chicago, Chicago University Press. KUKLICK Bruce, (1977), The Rise of American Philosophy, New Haven, Yale University Press. MANNHEIM Karl, (1936), Ideology and Utopia, L. Wirth \& E. Shils trans., New York, Harcourt, Inc. MARGolis Joseph, (2010), Pragmatism's Advantage, Stanford, Stanford University Press. 
MILL J.S., (1882), A System of Logic, New York, Harper \& Bros.

PEIRCE Charles S., (1931), Collected Papers, vol. 1., C. Hartshorne \& P. Weiss, eds., Cambridge, MA, Belknap Press of Harvard University Press.

ROULAND Norbert, (1994), Legal Anthropology, London, Athlone Press.

SCHELER Max, (1980), Problems of a Sociology of Knowledge, M. A. Frings trans., London, Routledge \& Kegan Paul.

STEIN Peter, (1980), Legal Evolution: The Story of an Idea, Cambridge, Cambridge University Press.

STIKKERS Kenneth, (1980), "Introduction," in Max Scheler, Problems of a Sociology of Knowledge, M. A. Frings trans., London, Routledge \& Kegan Paul.

STIKKERS Kenneth, (2009), "Dialogue Between Pragmatism and Constructivism in Historical Perspective," in L. Hickman, S. Neubert \& K. Reich (eds.), John Dewey Between Pragmatism and Constructivism, New York, Fordham University Press.

STONE Julius, (1985), Precedent and Law: Dynamics of Common Law Growth, Sydney, Butterworths.

SUNSTEIN Cass, (1999), A Case at a Time: Judicial Minimalism on the Supreme Court, Cambridge, Harvard University Press.

VAlVerde Mariana, (2003), Law's Dream of a Common Knowledge, Princeton, Princeton University Press.

WATSon Alan, (1985), The Evolution of Law, Baltimore, Johns Hopkins University Press.

WHITE G. Edward, (1972), “From Sociological Jurisprudence to Realism: Jurisprudence and Social Change in Early Twentieth-Century America," Virginia Law Review 58, 999-1028.

WHITE G. Edward, (1986), “From Realism to Critical Legal Studies: A Truncated Intellectual History," Southwestern Law Journal 40, 819-43.

WRIGHT Chauncey, (1873), “The Evolution of Self-Consciousness," North American Review 116, 245-310.

\section{ABSTRACTS}

Max Scheler followed American pragmatism in viewing knowledge as residing in concrete human acts, and both emphasized the role of social or community inquiry. How, given this insight, is knowledge to be understood? The answer must be sought within specific realms of inquiry, like science, where a sociology of scientific knowledge has emerged in the wake of Kuhn's Structure of Scientific Revolutions. What about law, if seen as another form of community inquiry? We may find a sociology of legal knowledge implicit in the work of pragmatism's classical legal theorist, Oliver Wendell Holmes Jr. Unlike Durkheim, Holmes does not hold that categories of thought reflect features of group organization and social solidarity. The nature and modes of legal classification emerge against a historical background from resolution of conflicts among disparate interests. Holmes's model is more skeptical of progress than Scheler's, but accepts a role for meliorative intelligence in revising embedded habits and paradigms. 


\section{AUTHOR}

\section{FREDERIC R. KELLOGG}

The George Washington University

frederickellogg[at]cd.com 